\title{
Instituto de Estudos Brasileiros
}

JOSÉ SEBASTIÄO WITTER

A cervo valioso... Riqueza incalculável... Fontes inesgotáveis para pesquisas nas diferentes áreas de estudo da Cultura Brasileira. Assim pode ser sintetizado o que significa o Instituto de Estudos Brasileiros (IEB-USP).

É um dos Institutos Especializados da Universidade de São Paulo e está organizado através de suas áreas específicas:

- a Administração;

- o Arquivo;

- a Biblioteca;

- a Coleçáo "Mário de Andrade" de Artes Visuais.

É o A, B, C da Instituiçáo.

Administrafáo: a área administrativa, suporte de toda instituição é das mais reduzidas da Universidade e tem demonstrado ser das mais eficientes. Prova que o que vale é a qualidade e não a quantidade...

Arquivo: este é a espinha dorsal da instituição. É o suporte a fornecer elementos seguros de informaçáo, tanto ao setor administrativo como à História. Nele estáo preservados documentos preciosos de Mário de Andrade, Graciliano Ramos, Guimaráes Rosa, Fernando de Azevedo, Fernando Mendes de Almeida, José de Freitas Valle, Theon Spanudis, Anita Malfatti, Ernani da Silva Bruno, Raul de Andrade e Silva, Pierre Monbeig.

Além do suporte tradicional, o papel, guarda também importantes informaçóes em fitas magnéticas, vídeocassetes, filmes e fotografias. Manuscritos e vídeos guardam a memória de personalidades de realce, mas também da Instituiçáo. Tradição e modernidade compóem a própria história...

Biblioteca: é o ponto central do IEB. Nela, pesquisadores maduros e aprendizes podem encontrar livros e livros que darão suporte às suas hipóteses de pesquisa. Talvez seja a mais importante coleçáo de obras sobre a Cultura e a História do Brasil existente em São Paulo, quiçá no Brasil. 
O acervo é um verdadeiro tesouro que cresce continuamente através de aquisiçóes ou por doaçōes generosas. Os pilares desse acervo, sobre o qual se constrói um belo edifício de idéias, são as coleçóes preciosas como Lamego, Yan de Almeida Prado, Mário de Andrade, Juarez Bezerra de Menezes, Guimarães Rosa, José Feliciano de Oliveira, Alfredo Ellis Jr.

Como se pode constatar, Arquivo e Biblioteca completam-se com as coleçóes que as compóem.

Colegáo de Artes Visuais "Mário de Andrade": é, por tudo que representa Mário de Andrade, o setor de destaque do Instituto.

Na sua ampla sala de exposiçóes está sempre à mostra a exposiçăo permanente do acervo de Mário de Andrade. É ele composto por obras do Modernismo Brasileiro, em que gravuras, pinturas e esculturas de artistas os mais significativos da história cultural do Brasil estáo reunidas. Podem-se admirar Anita Malfatti, Di Cavalcanti, Brecheret, Tarsila do Amaral, Lasar Segall, Cícero Dias, Ismael Nery... E mais, Portinari Guignard, Pancetti, Volpi, Rebolo, Clovis Graciano, Figueira...

Todo esse acervo está abrigado, desde 1993, em novo ambiente. Desde outubro, o IEB ocupa suas novas instalaçóes e, agora, está enriquecida com um mural de Tomie Ohtake, a compor o conjunto ambiental das pequenas praças interiores que dão ao IEB um ambiente moderno e acolhedor.

É um Instituto de pesquisa com um toque diferenciado e com muito calor humano...

Jose Sebasticto Witter é professor do Departamento de História da Faculdade de Filosofia, Letras e Ciências Humanas da USP e ex-diretor do IEB-USP (1990-94). 